\title{
Factors stimulating content marketing
}

\author{
Naser Azad", Seyed Mohsen Seyed AliAkbar and Sima Zomorodian
}

Department of Management and Accounting, South Tehran Branch, Islamic Azad University, Tehran, Iran

\begin{tabular}{l}
\hline C H R O N I C L E \\
\hline Article history: \\
Received October 28, 2015 \\
Received in revised format \\
November 28, 2015 \\
Accepted January 3, 2015 \\
Available online \\
January 4, 2016 \\
\hline Keywords: \\
Content marketing \\
Marketing \\
Banking industry
\end{tabular}
\begin{abstract}
A B S T R A C T
This paper presents an empirical investigation to determine factors influencing on content marketing in banking industry. The study designs a questionnaire consists of 40 questions in Likert scale and distributes it among 550 randomly selected regular customers of Bank Mellat in city of Tehran, Iran and 400 properly filled questionnaires are collected. Cronbach alphas for all components of the survey are well above desirable level. Using principle component analysis with Varimax rotation, the study has determined six factors influencing the most on content marketing including organization, details, having new ideas, quality, sensitivity and power while the last component contains only two subcomponents and is removed from the study.
\end{abstract}

\section{Introduction}

During the past few years, social media and generally online marketing has received more budget allocated (Forouzandeh et al., 2014). However, small firms, startups and individual entrepreneurs are jumping into the market of social media marketing without an appropriate preparation or strategy (Augustini, 2014). The digital content market has become an evolution in networking technologies, providing diverse insight about market. The digital content market has been growing quickly and traditional content providers encounter several service transformation decisions. Several studies on technology adoption have concentrated on issues like users and customers, cost reduction, or electronic channel related technologies. Jin and Li (2012) analyzed technology adoption decisions of competing firms for enhancing new content services from a strategic perspective. They investigated the impacts of market environments on firms' adoption decisions by utilizing game theoretical techniques. The study contributed a number of unique and interesting implications for the problems of emerging technology adoption for new content service provision.

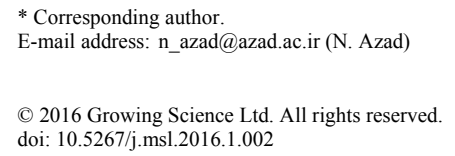


Zerbini et al. (2007) presented a competence-based concept of value-for-customer in business markets. The study investigated the relationship between strategy and marketing to have some insight about the competence-based roots of value creation. McKay-Nesbitt et al. (2013) determined gender differences in chronic regulatory focus and explained that congruence between message regulatory focus and the message recipient's gender is effective, more specifically for men who received content marketing on media. The results also indicated that emotions could mediate regulatory fit effects on intentions. O'Hern and Kahle (2013) discussed that the user-generated content (UGC) built by some consumers represents a profound shift of power from companies to consumers. In order to better learn this changing landscape, as well as to categorize different kinds of UGC in which customers most commonly engage, and highlight the advantages and challenges presented a new UGC typology that considers the objectives that consumers pursue as well as the kind of knowledge flow activated when consumers generate UGC.

Rowley (2008) argued that as the relative importance of digital content to business and society increases it is essential to look for a holistic perspective on the definition and nature of digital content marketing (DCM). A recurrent theme in DCM is associated with customer value and defining an exploration of the notion of customer value in digital content marketplaces. Many people define digital content as "bit-based objects distributed through electronic channels" (Koiso-Kanttila, 2004). Rowley (2008) performed a structured analysis on the basis of a set of questions to detect some of the unique characteristics of DCM. They described the potential of the "value-in-use" notion of customer value as a basis to make sure that consumers are fully engaged as stakeholders in the content economy. Ho and Dempsey (2010) investigated Internet users' motivations to pass along online content. They identified four potential motivations including "the need to be part of a group", "the need to be individualistic", "the need to be altruistic", and "the need for personal growth". They examined the relationship between these motivations and the frequency of passing along online content based on a survey accomplished among young adults. They reported that Internet users, who are more individualistic and/or more altruistic, more likely forward more online content than others do. Weber et al. (2006) performed a content analysis of food- and beverage-brand Web sites and the marketing techniques and advertising strategies available on these sites. They reported that with interactive media still in its developmental stage, it is necessary to develop safeguards for children.

\section{The proposed study}

This paper presents an empirical investigation to determine factors influencing on content marketing in banking industry. The study is accomplished among regular customers who do their daily banking activities with Bank Mellat in city of Tehran, Iran. The sample size is calculated as follows,

$$
N=Z_{\alpha / 2}^{2} \frac{p \times q}{e^{2}},
$$

where $N$ is the sample size, $p=1-q$ represents the probability, $z_{\alpha / 2}$ is CDF of normal distribution and finally $\varepsilon$ is the error term. For our study we assume $p=0.5, z_{\alpha / 2}=1.96$ and $e=0.05$, the number of sample size is calculated as $N=384$. The study designs a questionnaire consists of 40 questions in Likert scale and distributes it among 550 randomly selected regular customers of Bank Mellat in city of Tehran, Iran and 400 properly filled questionnaires are collected. Cronbach alphas for all components of the survey are well above desirable level.

Table 1

KMO and Bartlett's Test

\begin{tabular}{lrr} 
Kaiser-Meyer-Olkin Measure of Sampling Adequacy. & .921 \\
\hline & Approx. Chi-Square & 3307.093 \\
Bartlett's Test of Sphericity & df & 378 \\
& Sig. & .000 \\
\hline
\end{tabular}


Table 1 also shows the results of KMO and Bartlett's tests. Table 2 summarizes the results of total variance explained before rotation has accomplished. Table 3 presents the implementation of principal component analysis after rotation. Fig. 1 demonstrates personal characteristics of the participants in our survey.

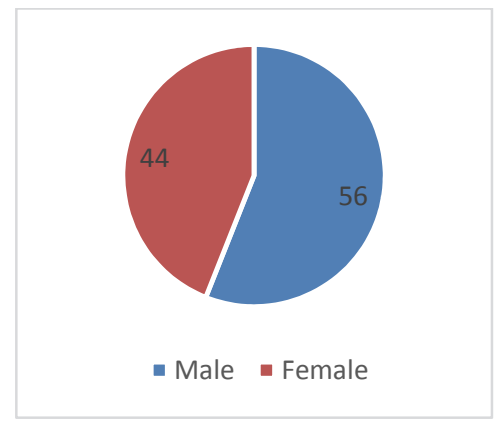

Gender

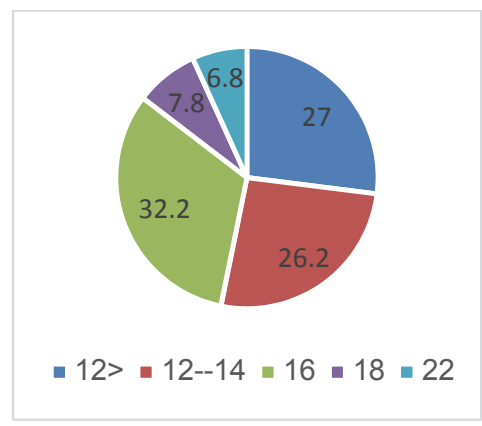

Years of education

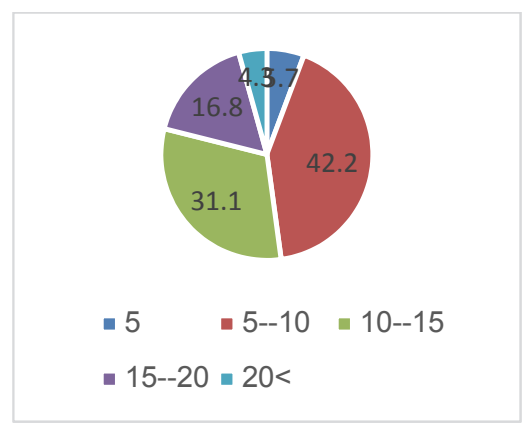

Years of education

Table 2

Fig. 1. Personal characteristics of the participants

The results principle component analysis

\begin{tabular}{|c|c|c|c|c|c|c|c|c|c|}
\hline \multirow[t]{2}{*}{ Component } & \multicolumn{3}{|c|}{ Initial Eigenvalues } & \multicolumn{3}{|c|}{ Extraction Sums of Squared Loadings } & \multicolumn{3}{|c|}{ Rotation Sums of Squared Loadings } \\
\hline & Total & $\%$ of Variance & Cumulative \% & Total & $\%$ of Variance & Cumulative \% & Total & $\%$ of Variance & Cumulative \% \\
\hline 1 & 5.914 & 29.569 & 29.569 & 5.914 & 29.569 & 29.569 & 2.440 & 12.199 & 12.199 \\
\hline 2 & 1.602 & 8.009 & 37.578 & 1.602 & 8.009 & 37.578 & 2.270 & 11.351 & 23.550 \\
\hline 3 & 1.172 & 5.861 & 43.439 & 1.172 & 5.861 & 43.439 & 2.026 & 10.130 & 33.680 \\
\hline 4 & 1.100 & 5.502 & 48.941 & 1.100 & 5.502 & 48.941 & 1.844 & 9.222 & 42.902 \\
\hline 5 & 1.036 & 5.178 & 54.119 & 1.036 & 5.178 & 54.119 & 1.636 & 8.180 & 51.083 \\
\hline 6 & 1.012 & 5.059 & 59.178 & 1.012 & 5.059 & 59.178 & 1.619 & 8.095 & 59.178 \\
\hline 7 & .795 & 3.973 & 63.151 & & & & & & \\
\hline 8 & .744 & 3.718 & 66.869 & & & & & & \\
\hline 9 & .716 & 3.582 & 70.451 & & & & & & \\
\hline 10 & .673 & 3.367 & 73.817 & & & & & & \\
\hline 11 & .652 & 3.260 & 77.078 & & & & & & \\
\hline 12 & .635 & 3.174 & 80.252 & & & & & & \\
\hline 13 & .573 & 2.865 & 83.117 & & & & & & \\
\hline 14 & .571 & 2.855 & 85.972 & & & & & & \\
\hline 15 & .543 & 2.715 & 88.687 & & & & & & \\
\hline 16 & .517 & 2.586 & 91.272 & & & & & & \\
\hline 17 & .488 & 2.439 & 93.712 & & & & & & \\
\hline 18 & .447 & 2.237 & 95.948 & & & & & & \\
\hline 19 & .411 & 2.056 & 98.004 & & & & & & \\
\hline 20 & .399 & 1.996 & 100.000 & & & & & & \\
\hline
\end{tabular}

Table 3

The summary of principle component analysis after rotation

\begin{tabular}{|c|c|c|c|c|c|c|}
\hline & \multicolumn{6}{|c|}{ Component } \\
\hline & 1 & 2 & 3 & 4 & 5 & 6 \\
\hline VAR00006 & .743 & & & & & \\
\hline VAR00007 & .667 & & & & & \\
\hline VAR00008 & .650 & & & & & \\
\hline VAR00005 & .577 & & & & & \\
\hline VAR00004 & .430 & & .389 & & & .363 \\
\hline VAR00036 & & .733 & & & & \\
\hline VAR00038 & & .689 & & & & \\
\hline VAR00040 & & .598 & & .342 & & \\
\hline VAR00028 & & .511 & & .420 & & \\
\hline VAR00001 & & & .788 & & & \\
\hline VAR00002 & & .332 & .721 & & & \\
\hline VAR00003 & & & .632 & & & \\
\hline VAR00027 & & & & .709 & & \\
\hline VAR00026 & & & & .680 & .396 & \\
\hline VAR00029 & & .444 & & .479 & & \\
\hline VAR00011 & & & & & .789 & \\
\hline VAR00010 & & & & & .611 & \\
\hline VAR00013 & & & & & .485 & .380 \\
\hline VAR00023 & & & & & & .689 \\
\hline VAR00025 & & & & .371 & & .574 \\
\hline
\end{tabular}

Extraction Method: Principal Component Analysis.

Rotation Method: Varimax with Kaiser Normalization.

a. Rotation converged in 11 iterations. 


\section{Results, discussion and conclusion}

As we can observe from the results of the survey, there are six factors influencing the most on content marketing including Organization, details, having new ideas, quality, sensitivity and power.

\subsection{Organization of content marketing}

The first component of the survey is associated with organization of content marketing, which consists of five components summarized in Table 4 as follows,

Table 4

The summary of the sub-component influencing on organization of content marketing

\begin{tabular}{|c|c|c|c|c|}
\hline Sub-component & Factor loading & Total variance & Accumulated & $\%$ \\
\hline Capability of converting value to the customer's perspective & 0.43 & 2.440 & 12.199 & 12.199 \\
\hline Information supplied to customer & 0.577 & & & \\
\hline Creating value content & 0.743 & & & \\
\hline Content message & 0.667 & & & \\
\hline Coordination between sender and receiver of message & 0.650 & & & \\
\hline
\end{tabular}

As we can observe from the results of Table 4, creating value content is believed to the most important factor followed by content of the messages sent to users, coordination between sender and receiver of message, information supplied to customer and capability of converting value to the customer's perspective. According to our survey, it is crucial to always create a good content for customer attraction and continuous improvement is also an important issue.

\subsection{Details of content marketing}

The second component of the survey is related to details of content marketing, which consists of four components summarized in Table 5 as follows,

\section{Table 5}

The summary of the sub-component influencing on details of content marketing

\begin{tabular}{|c|c|c|c|c|}
\hline Sub-component & Factor loading & Total variance & Accumulated & $\%$ \\
\hline Target customers & 0.511 & 2.270 & 23.550 & 11.351 \\
\hline Improvement on search engine keywords & 0.733 & & & \\
\hline Continuous surfing the social networks & 0.689 & & & \\
\hline Export social networks & 0.598 & & & \\
\hline
\end{tabular}

As we can see from the results of Table 5, improvement on search engine keywords is number one important factor followed by continuous surfing the social networks. The survey results indicate that a message with unique content plays essential role on attracting customer. The content also must preserve new ideas and informative topics.

\subsection{Content marketing with new ideas}

The third component of the survey is associated with content marketing with new ideas, which consists of three items summarized in Table 6 as follows,

\section{Table 6}

The summary of the sub-component influencing on details of content marketing

\begin{tabular}{lcccc}
\hline Sub-component & Factor loading & Total variance & Accumulated & $\%$ \\
\hline Customer outlook & 0.788 & 2.026 & 33.680 & 10.130 \\
Product life cycle & 0.721 & & & \\
New product development & 0.632 & & \\
\hline
\end{tabular}

As we can observe from the results of Table 6, customer outlook is the most important factor followed by product life cycle and new product development. 


\subsection{Quality of content marketing}

Quality of the content marketing is the fourth component of the survey, which consists of three items summarized in Table 7 as follows,

\section{Table 7}

The summary of the sub-component influencing on details of content marketing

\begin{tabular}{lcccc}
\hline Sub-component & Factor loading & Total variance & Accumulated & $\%$ \\
\hline Commercial trademark & 0.680 & 1.844 & 42.902 & 9.222 \\
Creating content & 0.709 & & \\
Sharing new ideas & 0.479 & & \\
\hline
\end{tabular}

As we can observe from the results of Table 7, creating appropriate content is the most important factor followed by commercial trademark and sharing new ideas.

\subsection{Sensitive content marketing}

Sensitive content marketing is the next component of the survey, which consists of three items summarized in Table 8 as follows,

\section{Table 8}

The summary of the sub-component influencing on details of content marketing

\begin{tabular}{lcccc}
\hline Sub-component & Factor loading & Total variance & Accumulated & $\%$ \\
\hline Market influence & 0.611 & 1.636 & 51.083 & 8.180 \\
The influence of trademark & 0.789 & & \\
Market uncertainty & 0.485 & & \\
\hline
\end{tabular}

As we can observe from the results of Table 8, the power and influence of trademark is the most important factor followed by market influence and market uncertainty.

\subsection{Content marketing power}

Content marketing power is the last component of the survey, which consists of two items summarized in Table 9 as follows,

\section{Table 9}

The summary of the sub-component influencing on details of content marketing

\begin{tabular}{lcccc}
\hline Sub-component & Factor loading & Total variance & Accumulated & $\%$ \\
\hline Capability of measuring content marketing & 0.689 & 1.619 & 59.178 & 8.095 \\
Providing relative information & 0.574 & & & \\
\hline
\end{tabular}

In our survey, we believe the last component does not preserve a good quality factor, since it contains only two sub-components and therefore, we remove it from our survey. We hope the management team of bank Mellat would be able to develop their content marketing by taking appropriate actions based on the results of this survey.

\section{Acknowledgement}

The authors would like to thank the anonymous referees for constructive comments on earlier version of this paper.

\section{References}

Augustini, M. (2014). Social Media and Content Marketing as a part of an effective Online Marketing strategy (Doctoral dissertation, Diploma thesis. Masaryk University: Faculty of informatics. Brno).

Forouzandeh, S., Soltanpanah, H., \& Sheikhahmadi, A. (2014). Content marketing through data mining on Facebook social network. Webology,11(1), 1. 
Ho, J. Y., \& Dempsey, M. (2010). Viral marketing: Motivations to forward online content. Journal of Business Research, 63(9), 1000-1006.

Jin, B. H., \& Li, Y. M. (2012). Analysis of emerging technology adoption for the digital content market. Information Technology and Management, 13(3), 149-165.

Koiso-Kanttila, N. (2004). Digital content marketing: a literature synthesis.Journal of Marketing Management, 20(1-2), 45-65.

McKay-Nesbitt, J., Bhatnagar, N., \& Smith, M. C. (2013). Regulatory fit effects of gender and marketing message content. Journal of Business Research, 66(11), 2245-2251.

O'Hern, M. S., \& Kahle, L. R. (2013). The empowered customer: User-generated content and the future of marketing. Global Economics and Management Review, 18(1), 22-30.

Rowley, J. (2008). Understanding digital content marketing. Journal of marketing management, 24(56), 517-540.

Weber, K., Story, M., \& Harnack, L. (2006). Internet food marketing strategies aimed at children and adolescents: a content analysis of food and beverage brand web sites. Journal of the American Dietetic Association,106(9), 1463-1466.

Zerbini, F., Golfetto, F., \& Gibbert, M. (2007). Marketing of competence: Exploring the resource-based content of value-for-customers through a case study analysis. Industrial Marketing Management, 36(6), 784-798.

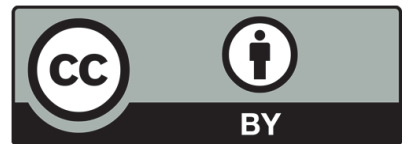

(C) 2016 by the authors; licensee Growing Science, Canada. This is an open access article distributed under the terms and conditions of the Creative Commons Attribution (CC-BY) license (http://creativecommons.org/licenses/by/4.0/). 